\title{
Study on Trophic State in Lakes of Dong Da District, Hanoi
}

\author{
Nguyen Thi The Nguyen* \\ Thuy Loi University, 175 Tay Son, Dong Da, Hanoi, Vietnam \\ Received 30 September 2017 \\ Revised 03 November 2017; Accepted 28 December 2017
}

\begin{abstract}
One of approaches to assessing the water quality of lakes is to look at their primary production or trophic state. Protecting water quality of urban lakes from eutrophication is an important task of all governments. This study presents an analysis of the trophic state of lakes in Dong Da district, Hanoi. The tropic states of the lakes were characterized using the Carlson TSI and the Chlorophyll-a concentrations and referenced with the thresholds of US. The deviations of the Secchi depth and total phosphorus indices from the Chlorophyll-a index were used to identify limiting factors affecting to the tropic state of the lakes. It comes to a conclusion that most of the lakes in study area were hypereutrophic or eutrophic in August 2017 and eutrophic or oligotropic in March 2017. It also reveals that phosphorus was not a limited factor for algal biomass while other factors such as nitrogen showed certain effects. The time plot method suggested that transparency was dominated by non-algal factors such as color and size, of suspended substances/ particles, whereas the difference plot method revealed that large particles were dominated in the studied lakes. Consequently, further studies should be done to find out the real causes of the lakes' eutrophication.
\end{abstract}

Keywords: Tropic state, lake, time pots, different pots.

\section{Introduction}

One of approaches to assessing the condition of lakes is to look at lakes with respect to their primary production [1]. Trophic state depicts biological productivity in lakes. Lakes are commonly classified according to their trophic state, a term that describes how "green" the lake is as measured by the amount of algae biomass in the water [2]. Lakes with high nutrient levels, high plant production rates, and an abundance of plant life are termed eutrophic, whereas lakes that have low

\footnotetext{
* Tel.: 84-983033532.

Email: nguyenntt@wru.vn

https://doi.org/10.25073/2588-1094/vnuees.4129
}

concentrations of nutrients, low rates of productivity and generally low biomass are termed oligotrophic. Lakes that fall in between are mesotrophic, and those on the extreme ends of the scale are termed hypereutrophic or ultraoligotrophic. Lakes exist across all trophic categories; however hypereutrophic lakes are usually the result of excessive human activity and can be an indicator of stress conditions [1].

In general, trophic state measurements serve as benchmarks for measuring the success of a lake management program [3]. There is no ideal trophic state for lakes as a whole since lakes naturally fall in all of these categories. Additionally, the determination of "ideal" trophic state depends on how the lake is used or managed [1]. For example, an oligotrophic lake 
is a better source of drinking water than a eutrophic lake because the water is easier or less expensive to treat. Swimmers and recreational users also prefer oligotrophic lakes because of their clarity and aesthetic quality. Eutrophic lakes can be biologically diverse with abundant fish, plants, and wildlife [4]. For anglers, increased concentrations of nutrients, algae, or aquatic plant life generally result in higher fish production. Eutrophication refers to nutrient enrichment of a body of water. Eutrophication is a slow, natural part of lake aging, but today human influences are significantly increasing the amount of nutrients entering lakes. Human activities such as poorly managed agriculture or suburbanization of lakeshores can result in excessive nutrient concentrations reaching lakes. This can lead to accelerated eutrophication and related undesirable effects including nuisance algae, excessive plant growth, murky water, odor, and fish kills [1].

There are various methods and indices to classify the tropic state of lakes. Initial determinations about the trophic state of a lake can be made by simply observing the lake's basic characteristics [3]. Vollenweider and Kerekes (1980) provide ranges of variable values associated with trophic levels on lakes [5]. The variable values associated with trophic levels in their study are total phosphorus (TP), total nitrogen (TN), Chlorophyll-a (Chl), Secchi depth (SD). Rast and Lee (1987) give a trophic state classification based on simple lake characteristics, including total aquatic plant production, number of algal species, characteristic algal groups, rooted aquatic plants, oxygen in hypolimnion, characteristic fish and SD [6]. Carlson (1977) constructs a trophic state index (TSI) based on three independent variables, including $\mathrm{Chl}$, TP and SD [7]. Kratzer and Brezonik (1981) propose a TSI related to the effect of nitrogen limitation using data from the National Eutrophication Survey on Florida lakes [8]. On the trophic state assessment of National Lakes in America in 2009, the analysts, in consultation with a number of state and local lake experts, decided to base trophic state on Chlorophyll-a concentrations. They considered this indicator the most relevant and straightforward estimate of trophic state because it is based on direct measurements of live organisms, yet acknowledges that other indicators also could be used [1].

The classical and most commonly method based on the productivity of the water body is the biomass related trophic state index developed by Carlson [2,9]. According to the US EPA, the Carlson index should only be used with lakes that have relatively few rooted plants and non-algal turbidity sources [10]. Because they tend to correlate, three independent variables can be used to calculate the Carlson index: Chlorophyll-a , total phosphorus and Secchi depth. Of these three, Chlorophyll-a will probably yield the most accurate measures, as it is the most accurate predictor of biomass. Phosphorus may be a more accurate estimation of a water body's summer trophic status than Chlorophyll-a if the measurements are made during the winter. Finally, the Secchi depth is probably the least accurate measure, but also the most affordable and expedient one. The Secchi depth, which measures water transparency, indicates the concentration of dissolved and particulate material in the water, which in turn can be used to derive the biomass. Lake managers need to keep in mind that the TSI classification scheme is a simple tool to provide benchmark information about the trophic state of a lake. When trophic state is used to classify a lake, lake managers are implying that algal biomass is the key parameter defining lake quality. For many urban lakes, the assumption that algal biomass is the primary management concern is entirely appropriate [3]. However, some shallow urban lakes may not fit this mold. These shallow urban lakes suffer from an overgrowth of emergent and/or submergent aquatic weeds, not algae. In these lakes, control of algal biomass might not be the primary concern. Lake managers should therefore understand the 
dynamic nature of their lake and prepare management strategies based on current and anticipated conditions. If the three Carlson trophic state values are not similar to each other, it is likely that algae may be light- or nitrogen-limited instead of P-limited or that Secchi depth is affected by erosional silt particles rather than by algae, or something else. If data for Chlorophyll-a and phosphorus are available, Chlorophyll-a is used as the primary index for trophic state classification. Then, the deviations of the Secchi depth and total phosphorus indices from the Chlorophyll-a index are used to infer additional information about the functioning of the lake [11].

This study presents an analysis of the trophic state in lakes of Dong Da district, Hanoi. First, the tropic states of the lakes are characterized using the Chlorophyll-a concentrations with the thresholds of US. Then the Carlson TSI was applied. Finally, the deviations of the Secchi depth and total phosphorus indices from the Chlorophyll-a index are used to identify limiting factors affecting to the tropic state of the lakes.

\section{Materials and methods}

\subsection{Study areas}

Dong Da district is located in the heart of Hanoi. Previously, in the area, there were many ponds and lakes, but with the process of urbanization, some ponds and lakes have been filled. Currently, Dong Da district has ten lakes, in which there are some large ones like Xa Dan, Dong Da, Ba Mau and Kim Lien. The main source of water for the lakes is rain runoff. Some lakes still receive wastewater such as Van Chuong, small Kim Lien, and Linh Quang lakes. Some morphological characteristics of the lakes are presented in Table 1. All of the lakes in the area are closed without water circulation so the capable of self-purification of the lakes is weak. The lakes have a great role in climate regulation, flood control, and urban landscape. Therefore, protecting water quality of lakes is a very important task of the Hanoi's government.

From 2015 up to now, the People's Committee of Dong Da district has carried out yearly reports on the environmental protection in the district, including water quality monitoring in the lakes. The number of water quality samples in each lake is shown in Table 1. The samples are taken at about 1-2 meter from the bank of the lakes, $20 \mathrm{~cm}$ below the water surface and stored in polyethylene bottles. The parameters of TP, SD and Chl for this study were analyzed at the Environmental chemistry lab of the Thuy loi University. Total phosphorus is determined by the spectroscopic method on the 6300 spectrophotometer (Jenway - UK). Chlorophyll a was determined by the TriLux Multi-parameter algae sensor (Chelsea UK). The Secchi depths were measured by the Secchi Disk 3-58-A25 Wildco (US).

Table 1. Some morphological characteristics of the lakes in Dong Da district, Hanoi

\begin{tabular}{|c|c|c|c|c|}
\hline Name of lake & Area (ha) & Average depth (m) & Max water level (m) & Number of samples \\
\hline Dong Da & 18.6 & $1.0-2.0$ & 4.6 & 5 \\
\hline Ho Van & 2.5 & $1.5-2.0$ & 5.2 & 3 \\
\hline Linh Quang & 3.0 & 3.0 & 5.2 & 3 \\
\hline Van Chuong & 2.8 & $2.0-3.0$ & 5.2 & 3 \\
\hline Xa Dan & 5.0 & 4.0 & 4.6 & 4 \\
\hline Kim Lien & 5.0 & $1.5-2.0$ & 5.2 & 4 \\
\hline $\mathrm{Ba} \mathrm{Mau}$ & 4.5 & $2.0-3.0$ & 5.1 & 4 \\
\hline Hao Nam & 0.75 & 3.5 & - & 1 \\
\hline Ho Me & 1.3 & 3.5 & - & 1 \\
\hline Lang Thuong & 5 & $3.5-4$ & - & 3 \\
\hline
\end{tabular}




\subsection{Trophic state analysis}

In this study, the trophic state in the lakes were assessed based on Chl concentrations and the trophic state index (TSI) of Carlson.

Chlorophyll-a and trophic state: According to U.S. EPA [1], a lake is oligotropic when Chl concent is equal or below $2 \mathrm{ug} / \mathrm{L}$, mesotrophic when $\mathrm{Chl}$ concentration is from 2 to $7 \mathrm{ug} / \mathrm{L}$, eutrophic when Chl concentration is from 7 to $30 \mathrm{ug} / \mathrm{L}$ and hypereutropic when $\mathrm{Chl}$ concentration is above $30 \mathrm{ug} / \mathrm{L}$.

Trophic state indices: The trophic state index (TSI) of Carlson was calculated using the following formula [7]:

TSI for Chl $(\mathrm{ug} / \mathrm{L}): \mathrm{TSI}(\mathrm{Chl})=9.81 \ln (\mathrm{Chl})$ $+30.6(1)$

TSI for SD (meters): TSI(SD) $=60-14.41$ $\ln (\mathrm{SD})(2)$

TSI for TP $(\mathrm{ug} / \mathrm{L})$ : $\mathrm{TSI}(\mathrm{TP})=14.42 \ln (\mathrm{TP})$ $+4.15(3)$

where TSI is the trophic state index and " $\ln$ " is the natural logarithm.

Carlson trophic state index: (CTSI) =

$[\mathrm{TSI}(\mathrm{TP})+\mathrm{TSI}(\mathrm{Chl})+\mathrm{TSI}(\mathrm{SD})] / 3$ (4)

Based on the values of CTSI, the lakes are classified as oligotrophic (CTSI $\leq 40)$, mesotrophic $(40<\mathrm{CTSI} \leq 50)$ and eutrophic $(50<\mathrm{CTSI} \leq 70)$ and hypereutrophic (CTSI $>70)$.

The three index variables are interrelated by linear regression models, and should produce the same index value for a given combination of variable values. A lack of agreement of the indices suggests that something is different between the variable relationships as originally derived for the index and either the analytical method or the relationship between variables in the new dataset [12, 13]. Deviations can identify either methodological differences or provide additional insight into the lake's dynamics.

\subsection{Graphical methods of identifying limiting factors}

Deviations of the TSI(Chl), both positive and negative, from the TSI(TP) and the TSI(SD) can be used to infer various situations of lakes [13]. Carlson [14] suggested that, in general, deviations of TSI(Chl) from the TSI(TP) indicate degrees of P limitation, while deviations of TSI(Chl) from TSI(SD) indicate the degree of light penetration relative to the number and size of seston particles. If TSI (TP) and TSI (SD) both deviate from TSI (Chl) but are themselves correlated, then non-algal turbidity is indicated. Two methods are given below that utilize these deviations to provide inferences about the workings of lakes and reservoirs.

\section{Time plots}

This method simply plots the three variables against a variable such as time, season or space [13]. Since all three variables should center or vary randomly around the same index value, the degree of variation of any one or two variables is a measure of the residual error. By examining deviations listed in Table 2, inferences can be made as to possible explanations for the observed deviation. This plot is especially useful for identifying seasonally-varying deviations, such as seasonal changes in the relative amount of nitrogen or phosphorus, episodes of zooplankton grazing.

Table 2. Conditions associated with differences between trophic state indices

\begin{tabular}{ll}
\hline \multicolumn{1}{c}{ Relationship between TSI variables } & Conditions \\
\hline $\mathrm{TSI}(\mathrm{Chl})=\mathrm{TSI}(\mathrm{TP})=\mathrm{TSI}(\mathrm{SD})$ & Algae dominate light attenuation; TN/TP $\sim 33: 1$ \\
$\mathrm{TSI}(\mathrm{Chl})>\mathrm{TSI}(\mathrm{SD})$ & Large particulates, such as Aphanizomenon flakes, dominate \\
$\mathrm{TSI}(\mathrm{TP})=\mathrm{TSI}(\mathrm{SD})>\mathrm{TSI}(\mathrm{CHL})$ & Non-algal particulates or color dominate light attenuation \\
$\mathrm{TSI}(\mathrm{SD})=\mathrm{TSI}(\mathrm{CHL})>\mathrm{TSI}(\mathrm{TP})$ & Phosphorus limits algal biomass (TN/TP >33:1) \\
& Algae dominate light attenuation but some factor such as nitrogen \\
$\mathrm{TSI}(\mathrm{TP})>\mathrm{TSI}(\mathrm{CHL})=\mathrm{TSI}(\mathrm{SD})$ & limitation, zooplankton grazing or toxics limit algal biomass. \\
& Source: Carlson, 2005
\end{tabular}




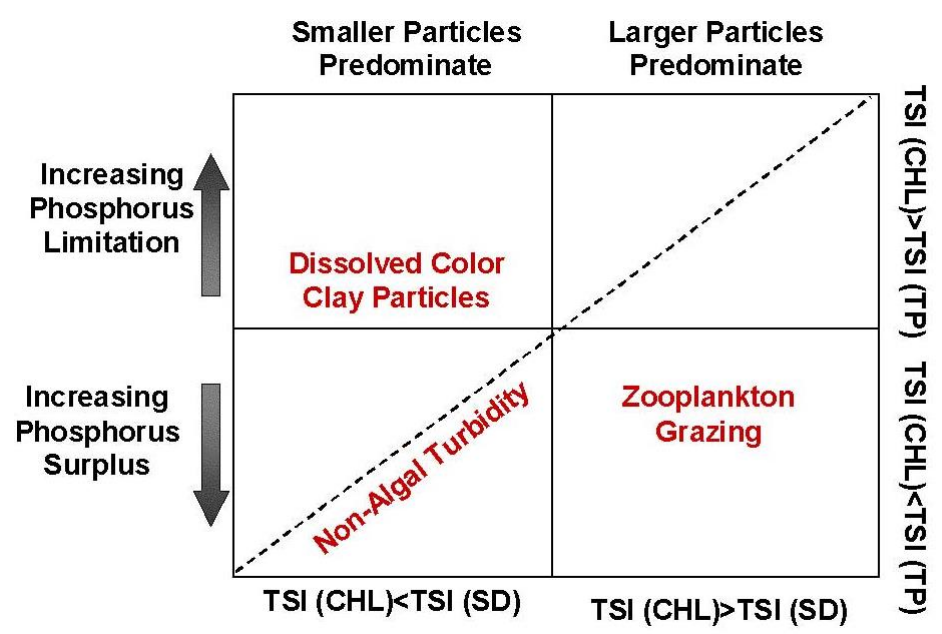

Figure 1. A representation of possible explanations of deviations of the trophic state index equations Source: Carlson, 2005

\section{Difference plots}

Carlson (1992) proposed a method, where both deviations, [TSI(Chl) - TSI(TP)] and [TSI(CHL) - TSI(SD)], are plotted on a single graph (Fig. 1). If [TSI(Chl) - TSI(TP)] is plotted on the Y-axis, then points above the origin represent instances where there is more Chlorophyll-a than predicted by the TP concentration, while points below the origin suggest instances where there is less Chl than predicted by TP. One interpretation of vertical deviations would be that it represents the degree to which algae are limited by phosphorus. Points lying on the $\mathrm{X}$-axis [TSI(Chl) - TSI(SD)] to the right of the $\mathrm{Y}$-axis indicate instances where there is more $\mathrm{Chl}$ than predicted by SD, such as if the $\mathrm{Chl}$ is packaged in large filamentous or colonial blue-green algae, which attenuate less light than an equal biomass of smaller algal particles. Points on the $\mathrm{X}$-axis to the left of the $\mathrm{Y}$ axis indicate instances where TSI (SD) over-predicts the TSI (Chl), which might occur if light is scattered or absorbed by very small particles such as suspended clays or by colored dissolved matters.

Havens et al. [15] suggested that in some lakes, a predominance of pico-plankton-sized algae might also result in negative deviations between TSI(Chl) and TSI(SD). Points lying on the diagonal to the left of the origin indicate situations where phosphorus and transparency are correlated, but not Chlorophyll-a. Points on or near this line would be found in turbid situations where phosphorus is bound to clay particles and therefore turbidity and phosphorus are related, but not Chlorophyll-a.

\section{Results and discussion}

\subsection{Trophic state in lakes of Dong Da district, Hanoi}

Concentrations of Chlorophyll-a, TP, SD in the lakes of Dong Da district in 2017 are shown in Table 3. The results of TSI calculation and tropphic state assessment for the lakes are presented in Table 4. 
Table 3. Average concentrations of Chlorophyll-a, TP, SD in the lakes of Dong Da district

\begin{tabular}{|c|c|c|c|c|c|c|}
\hline \multirow{3}{*}{ Name of lake } & \multicolumn{6}{|c|}{ Average concentration } \\
\hline & \multicolumn{2}{|c|}{ Chlorophyll-a } & \multicolumn{2}{|c|}{ TP } & \multicolumn{2}{|c|}{ SD } \\
\hline & $8 / 2017$ & $3 / 2017$ & $8 / 2017$ & $3 / 2017$ & $8 / 2017$ & $3 / 2017$ \\
\hline Dong Da & 11.3 & 7.0 & 2430 & 2060 & 0.9 & 1.1 \\
\hline Ho Van & 5.6 & 2.2 & 244 & 153 & 1.0 & 1.4 \\
\hline Linh Quang & 6.2 & 1.4 & 1270 & 1140 & 1.2 & 1.2 \\
\hline Van Chuong & 8.7 & 2.4 & 383 & 343 & 0.8 & 1.1 \\
\hline Xa Dan & 6.7 & 2.3 & 438 & 271 & 0.9 & 1.0 \\
\hline Kim Lien & 7.3 & 5.6 & 1040 & 1204 & 1.1 & 1.2 \\
\hline $\mathrm{Ba} \mathrm{Mau}$ & 5.0 & 2.4 & 859 & 680 & 0.8 & 0.9 \\
\hline Hao Nam & 2.7 & 0.7 & 2680 & 3300 & 0.7 & 1.0 \\
\hline Ho Me & 5.0 & 1.5 & 205 & 248 & 1.7 & 2.0 \\
\hline Lang Thuong & 6.0 & 1.4 & 3230 & 3120 & 1.3 & 1.5 \\
\hline
\end{tabular}

Table 4. The results of TSI calculation for in the lakes of Dong Da district

\begin{tabular}{|c|c|c|c|c|c|c|c|c|}
\hline \multirow{3}{*}{$\begin{array}{l}\text { Name of } \\
\text { lake }\end{array}$} & \multicolumn{8}{|c|}{ Trophic state index } \\
\hline & \multicolumn{2}{|c|}{ Chl } & \multicolumn{2}{|c|}{ TP } & \multicolumn{2}{|c|}{ SD } & \multicolumn{2}{|c|}{ CTSI } \\
\hline & $8 / 2017$ & $3 / 2017$ & $8 / 2017$ & $3 / 2017$ & $8 / 2017$ & $3 / 2017$ & $8 / 2017$ & $3 / 2017$ \\
\hline Dong Da & 54 & 50 & 117 & 114 & 62 & 59 & 77 & 74 \\
\hline Ho Van & 48 & 38 & 83 & 77 & 60 & 55 & 64 & 57 \\
\hline Linh Quang & 48 & 34 & 107 & 106 & 57 & 57 & 71 & 66 \\
\hline Van Chuong & 52 & 39 & 90 & 88 & 63 & 59 & 68 & 62 \\
\hline Xa Dan & 49 & 39 & 92 & 85 & 62 & 60 & 68 & 61 \\
\hline Kim Lien & 50 & 48 & 104 & 106 & 59 & 57 & 71 & 70 \\
\hline $\mathrm{Ba} \mathrm{Mau}$ & 46 & 39 & 102 & 98 & 63 & 62 & 70 & 66 \\
\hline Hao Nam & 40 & 27 & 118 & 121 & 65 & 60 & 74 & 69 \\
\hline Ho Me & 46 & 35 & 81 & 84 & 52 & 50 & 60 & 56 \\
\hline Lang Thuong & 48 & 34 & 121 & 120 & 56 & 54 & 75 & 69 \\
\hline
\end{tabular}

As can be seen in the table 4, the CTSI values of the lakes recorded in between 56 to 77 and showed seasonal fluctuations. The rainfall in Hanoi (measured at Lang station) varies considerably in rainy seasons (average $57 \mathrm{~mm}$ in March) and in dry seasons (average $332 \mathrm{~mm}$ in August) [16], so the water levels in the lakes are seasonal fluctuations. Our study revealed the fact that the CTSI values are higher during rainy season, lesser during dry season (Table 5). The results of CTSI classify most of the lakes in Dong Da district as eutrophic. Linh Quang,
Kim Lien, Lang Thuong and Hao Nam lakes had a worse tropic state in the summer 2017. During this period, these lakes were hypereutrophic. Dong Da lake was hypereutrophic in both period of examination. However, the trophic state assessment based on the Chl concentrations gave a bit different results. According to this method, all lakes were eutrophic in August 2017. In March 2017, Linh Quang, Hao Nam and Lang Thuong lakes were oligotropic. The remains were mesotrophic. 
Table 5. Results of the trophic state assessment for the lakes in Dong Da district, Hanoi

\begin{tabular}{lllll}
\hline \multirow{2}{*}{ Name of lake } & \multicolumn{4}{c}{ Tropic state } \\
\cline { 2 - 5 } & \multicolumn{3}{c}{ Based on CTSI } & \multicolumn{1}{c}{ Based on Chl content } \\
\cline { 2 - 5 } & $8 / 2017$ & hypereutrophic & eutrophic & mesotrophic \\
\hline Dong Da & hypereutrophic & eutrophic & eutrophic & mesotrophic \\
Ho Van & eutrophic & eutrophic & eutrophic & oligotropic \\
Linh Quang & hypereutrophic & eutrophic & eutrophic & mesotrophic \\
Van Chuong & eutrophic & eutrophic & eutrophic & mesotrophic \\
Xa Dan & eutrophic & eutrophic & eutrophic & mesotrophic \\
Kim Lien & hypereutrophic & eutrophic & eutrophic & mesotrophic \\
Ba Mau & eutrophic & eutrophic & eutrophic & oligotropic \\
Hao Nam & hypereutrophic & eutrophic & eutrophic & mesotrophic \\
Ho Me & eutrophic & eutrophic & eutrophic & oligotropic \\
Lang Thuong & hypereutrophic & & & \\
\hline
\end{tabular}

It should be paid attention that the results of trophic state assessment for Lang Thuong lake were totally different between the two methods in March 2017. The CTSI classified this lake as eutrophic while the method based on Chl contents defined this lake as oligotropic. The reason for this difference is due to a high concentration of TP in the lake resulting in the increases in the TSI (TP) and CTSI values. Whereas the concentration of $\mathrm{Chl}$ in the lake was rather low, resulting in the oligotropic trophic state.

\subsection{Identifying limiting factors of trophic state}

The graphical representations of the Carlson trophic state indices of the lakes are given in Figure 2, 3, 4 and 5. As can be seen on Figure 2 and 3, the Chlorophyll-a and transparency indices are both fall below the phosphorus curve $(\mathrm{TSI}(\mathrm{TP})>\mathrm{TSI}(\mathrm{SD})>\mathrm{TSI}(\mathrm{Chl})$. This might suggest that the algae are nitrogenlimited or at least limited by some other factor than phosphorus. The monitoring data also shown that the phosphorus contents in the lakes were very high and in excess of demands by phytoplankton. For example, the phosphorus contents in Kim Lien, Ba Mau, Linh Quang, Xa Dan lakes in 2016 were correspondingly 3.6, 2.6, 5.7, 1.3 times higher than the standard value for irrigation and navigation (column B1) in the National technical regulation on surface water quality (QCVN 08-MT: 2015/BTNMT) [16]. Intense zooplankton grazing, for example, may cause the Chlorophyll-a and Secchi depth indices to fall below the phosphorus index as the zooplankton remove algal cells from the water or Secchi depth may fall below Chlorophyll-a if the grazers selectively eliminate the smaller cells. It means that the zooplankton grazing has reduced the number of smaller particles, leaving larger particles [13]. Biomass has been reduced below levels predicted from total phosphorous. TSI(TP) > TSI(Chl) could reveal that toxics limit algal biomass. Biomass has been reduced below levels predicted from total phosphorous. 


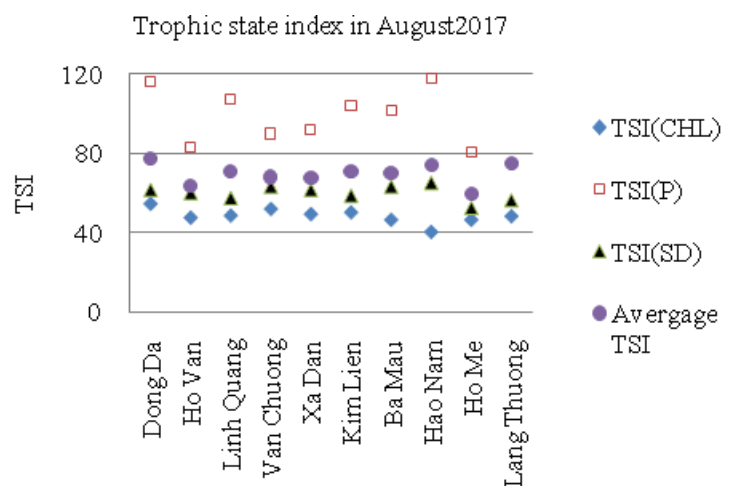

Figure 2. Time plot representing changes in TSI in August 2017.

Difference plots of TSI values are plotted in Figure 4 and 5. It can be seen that all points are on the left of the $\mathrm{Y}$-axis and below the $\mathrm{X}$-axis. It would be related to situations where transparency is dominated by non-algal factors such as color or turbidity or where very small particles predominate. Moreover, it would be associated situations where Chlorophyll-a is under-predicted by total phosphorus, i.e., situations where phosphorus may not be limiting Chlorophyll-a. Carlson [12] reported that this $\mathrm{X}$-zero line is related to total nitrogen

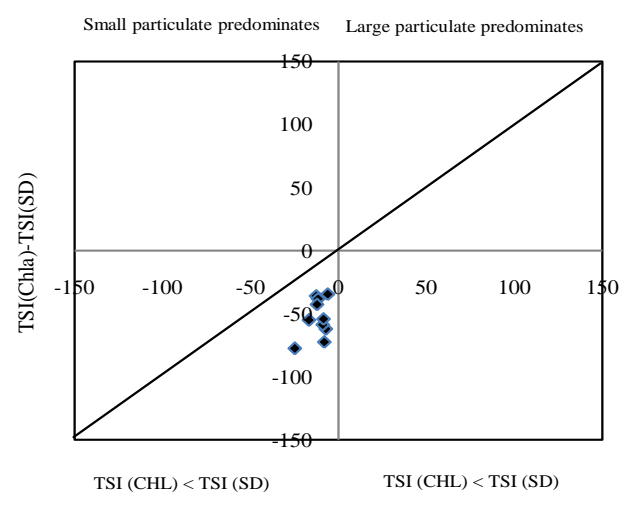

TSI(Chla)-TSI(P)

Fig. 4. Difference plots of TSI values in August 2017.

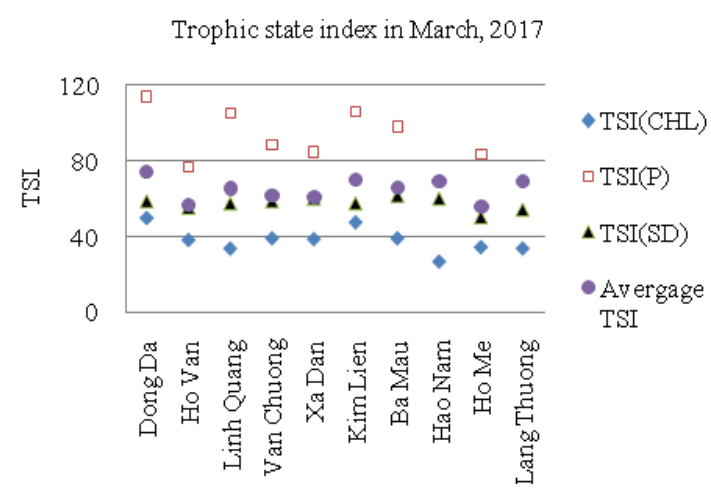

Figure 3. Time plot representing changes in TSI in March 2017.

to total phosphorus (TN/TP) ratios greater than 33:1. For the case of the lakes in Dong Da district, all of the deviation points are below the zero line. It indicates nitrogen limitation and TN/TP ratio is smaller than 33:1.

The Figure 4 and 5 also show that all deviation points lye near the diagonal to the left of the origin. This would be found in turbid situations where phosphorus is bound to clay particles and therefore turbidity and phosphorus are related, but not Chlorophyll-a.

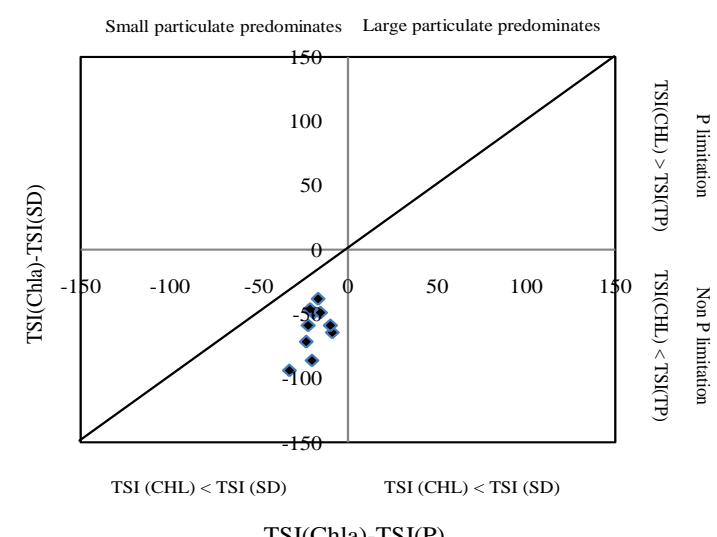

Fig. 5. Difference plots of TSI values in March 2017. 


\section{Conclusions}

According to the Carlson TSI and the Chlorophyll-a concentrations with the thresholds of US, most of the lakes in the study area were hypereutrophic or eutrophic in August 2017 and eutrophic or oligotropic in March 2017. The assessment by the Carlson TSI showed a worse trophic state than the method based on Chlorophyll-a concentrations. Phosphorus might not limit algal biomass but some factors such as nitrogen limitation, zooplankton grazing. The time plot method suggested that transparency were dominated by non-algal factors such as color or turbidity or where very small particles predominated, whereas the difference plot method revealed that large particles were dominated. Consequently, more studies should be done to look for the real limiting factors and conditions of the lakes.

\section{Acknowledgments}

The author would like to thank the Dong Da People's Committee for data supporting for the study.

\section{References}

[1] U.S. EPA, National Lakes Assessment: A Collaborative Survey of the Nation's Lakes, EPA 841-R-09-001, Washington, D.C, 2009.

[2] Prasad, A. G. D. and Siddaraju, Carlson's Trophic State Index for the assessment of trophic status of two Lakes in Mandya district, Advances in Applied Science Research 3 (5) (2012), 29922996.

[3] Thomas R. Schueler, Urban Lake Management, Center for Watershed Protection, US, 2001.

[4] Toronto and Region Remedial Action Plan, Preliminary Assessment of the Eutrophication or Undesirable Algae Beneficial Use Impairment (BUI) Along the Toronto and Region Waterfront, 2015.

[5] Vollenweider, R.A. and J.J. Kerekes., Background and Summary Results of the OECD
Cooperative Program on Eutrophication, In: Proceedings of an International Symposium on Inland Waters and Lake Restoration. U.S. Environmental Protection Agency. EPA 440/581-010 (1980), 26-36.

[6] Rast, W. and G.F. Lee., Summary Analysis of the North American (US Portion) OECD Eutrophication Project: Nutrient Loading-Lake Response Relationship and Trophic State Indices, US EPA. Corvallis Environmental Research Laboratory. Corvallis, OR. EPA-600/3-78-008, 1987.

[7] Carlson, Robert E., A trophic state index for lakes, Limnological Research Center, University of Minnesota, 1977.

[8] Kratzer, C.R. and P.L. Brezonik, A Carlson-type trophic state index for nitrogen in Florida lakes, Water. Res. Bull. 17 (1981), 713-715.

[9] Murthy, G.P., Shivalingaiah, Leelaja, B.C., Hosmani, S.P, Trophic State Index in Conservation of Lake Ecosystems, Proceedings of Taal2007: The $12^{\text {th }}$ World lake Conference, 840843.

[10] U.S. EPA, Carlson's Trophic State Index. Aquatic Biodiversity, United States Environmental Protection Agency, 2007. http://www.epa.gov/ bioindicators/aquatic/carlson.html accessed 17 February 2008.

[11] Trophic State Equations, http://www.secchidipin. org/index.php/monitoring-methods/trophic-stateequations/, accessed date: 20/8/2017.

[12] Carlson, R.E., Expanding the trophic state concept to identify non-nutrient limited lakes and reservoirs, In Proceedings of a National Conference on Enhancing the States' Lake Management Programs. Monitoring and Lake Impact Assessment. Chicago (1992), 59-71.

[13] Carlson, R. E., Havens, K. E., Simple Graphical Methods for the Interpretation of Relationships Between Trophic State Variables, Lake and Reservoir Management, 21(1) (2005), 107-118, DOI: 10.1080/07438140509354418.

[14] Carlson, R.E., Discussion on "Using differences among Carlson's trophic state index values in regional water quality assessment," by Richard A. Osgood. Wat. Res. Bull. 19 (1983), 307- 309.

[15] Havens, K.E., H.J. Carrick, E.F. Lowe and M.F. Coveney, Contrasting relationships between 
nutrients, Chlorophyll a and Secchi transparency in two shallow subtropical lakes: Lakes Okeechobee and Apopka (Florida, USA), Lake and Reserv. Manage. 15 (2000), 298-309.
[16] Dong Da People's Committee, Report on environmental protection mission, Dong Da district, 2016

[17] Dong Da People's Committee, Water monitoring data in lakes of Dong Da district, 2017.

\title{
Nghiên cứu mức độ dinh dưỡng của các hồ thuộc quận Đống Đa, Hà Nội
}

\author{
Nguyễn Thị Thế Nguyên \\ Đại học Thủy lợi, 175 Tây Son, Hà Nội, Việt Nam
}

Tóm tắt: Một trong những cách tiếp cận đánh giá chất lượng nước của hồ là xem xét năng suất sơ cấp hay trạng thái dinh dưỡng của hồ. Bảo vệ chất lượng nước các hồ không bị phì dưỡng là một nhiệm vụ quan trọng của tất cả các quốc gia. Bài báo này trình bày nghiên cứu về trạng thái dinh dưỡng ở các hồ của quận Đống Đa, Hà Nội. Trạng thái dinh dưỡng của hồ được phân loại theo chỉ số Carlson và theo nồng độ Chlorophyll-a với ngưỡng cho phép của Mĩ. Độ lệch của chỉ số độ sâu Secchi và tổng photpho so với chỉ số Chlorophyll-a được sử dụng để xác định các yếu tố ảnh hưởng đến trạng thái dinh dưỡng của các hồ. Kết quả nghiên cứu cho thấy hầu hết các hồ trong khu vực nghiên cứu đều bị phú dưỡng hoặc siêu phú dưỡng vào tháng 8 năm 2017 và trung dưỡng hoặc phú dưỡng vào tháng 3 năm 2017. Photpho không phải là yếu tố giới hạn đối với sinh khối tảo mà do yếu tố khác như nitơ. Phương pháp biểu đồ thời gian cho thấy độ trong của nước hồ bị chi phối bởi các yếu tố không liên quan đến tảo như màu sắc của các chất trong nước hoặc do các hạt lơ lửng kích thước nhỏ. Trong khi đó, phương pháp biểu đồ khác biệt cho thấy các hạt lơ lửng kích thước lớn chiếm ưu thế trong các hồ. Nghiên cứu đề xuất cần có thêm nhiều nghiên cứu để tìm ra các điều kiện ảnh hưởng đến sinh khối tảo và độ trong của các hồ này.

Tù khóa: Trạng thái dinh dưỡng, ao hồ, biểu đồ thời gian, biểu đồ khác biệt. 